\title{
Effects of Passive Smoking Associated with Physical Exercise in the Skeletal Muscles of Rats During Pregnancy and Lactation
}

\author{
Efectos del Tabaquismo Pasivo Asociado con el Ejercicio Físico en los \\ Músculos Esqueléticos de Ratas Durante la Gestación y Lactancia
}

\begin{abstract}
Bruna Corral Garcia Valsoni"; Mariana Rotta Bonfim*; Regina Celi Trindade Camargo*;
\end{abstract} Luiz Carlos de Abreu**; Dorotéia Rossi Silva Souza*** \& José Carlos Silva Camargo Filho*

VALSONI, B. C. G.; BONFIM, M. R.; CAMARGO, R. C. T.; ABREU, L. C.; SOUZA, D. R. S. \& CAMARGO FILHO, J. C. S. Effects of passive smoking associated with physical exercise in the skeletal muscles of rats during pregnancy and lactation. Int. $\boldsymbol{J}$. Morphol., 33(2):497-506, 2015.

SUMMARY: The objective of this study was to analyze the effects of passive smoking, in soleus and gastrocnemius muscles associated with physical exercise by swimming during pregnancy and lactation of rats. Twenty-four rats were divided: GF (exposed to cigarette smoke), GC (control), GFN (underwent to the swimming program and exposed to cigarette smoke) and GN (underwent to the swimming program). On the first day of pregnancy procedure of exposure to cigarette smoke began, consisting in 30 minutes twice a day for six weeks. During the same period the swimming program began, which lasted 60 min every day untilthe 21 st day of lactation. Soleus and gastrocnemius muscles, were obtained for histological, histochemical, morphometric analysis and fiber profiling. In histology, the groups GF and GFN showed infiltrations, necrotic and phagocytized fibers, centralized nuclei, splittings and coiling; in GN changes were observed due to exercise adaptations, infiltrations, sarcolemal lesion, polymorphic, atrophic and angular fibers. In the histochemical analysis of the groups GF and GFN there was enzymatic activity and amorphous formazan aggregates in subsarcolemmal positions, however in GN the same changes were found in lower frequency and intensity. In regard to the measure of the cross-section of muscle fibers there weren't significant differences among the groups, as well as, in the frequency of types of fibers of the gastrocnemius. It is concluded that aerobic exercise is not enough to impede morphological and histochemical changes caused in an animal model of pregnant and lactating associated with smoking, and the stress not influence the types and size of muscle fibers.

KEY WORDS: Passive Smoking; Physical Exercise; Pregnancy; Lactation; Skeletal Muscle.

\section{INTRODUCTION}

Passive smoking is characterized by inhalation of side-stream smoke, produced by the slow-burning ends of cigarettes between puffs, as well as, by inhalation of mainstream smoke exhaled by smokers (Rogers, 2009). Side-stream smoke is a complex mixture composed of more than 5000 chemical compounds, which shows concentrations ten times higher than the nicotine, tar and carbon monoxide in smoke inhaled by active smokers. However, a passive smoker inhales fewer cigarette components, still harmful, due to the progressive dilution of smoke in the air (Brownson et al., 2002).
When the passive smoker is a pregnant woman, the losses go farther, because exposure to cigarette smoke is a substantial cause of fetal morbidity and mortality (Coleman 2008), as well as the responsible factor for delaying the development of infants (Mello et al., 2001). In the last years, several studies have reported only the consequences of maternal passive smoking to the fetus and newborns (Mello et al., 2001, 2006), but little is known about the consequences to the mother.

During pregnancy women seek for a healthier

Laboratório de Histologia, Departamento de Fisioterapia, Faculdade de Ciências e Tecnologia, Universidade Estadual Paulista (FCT/UNESP), Presi dente Prudente, Brasil.

** Laboratório de Delineamento de Estudos e Escrita Científica na Faculdade de Medicina do ABC, São Paulo, Brasil.

**** Núcleo de Pesquisa em Bioquímica e Biologia Molecular, Departamento de Biologia Molecular, Faculdade de Medicina de São José do Rio Preto(FAMERP), São José do Rio Preto, Brasil. 
lifestyle with more balanced diets and physical exercise, because it improves the cardiorespiratory condition, controls weight gain (Cavalcante et al., 2009), besides, prevents diseases such as hypertension, diabetes, postpartum obesity (Melzer et al., 2010). Within the skeletal muscle realm, the benefits of physical exercise are to alleviate leg cramps and muscle fatigue, to improve agility and ability to perform daily activities, to alleviate and to prevent backaches caused by the increase in lumbar curvature (Cavalcante et al.; Melzer et al.). On the other hand, it is known that physical exercise is also associated with the occurrence of adaptations in skeletal muscles, which include alterations in metabolic and structural characteristics, also leading to the onset of inflammation caused by micro lesions (Baldwin \& Haddad, 2002).

Studies (Chattopadhyay \& Chattopadhyay, 2008; Montes de Oca et al., 2008) relate data from pathological examinations, as instances of inflammation in segments of muscle fibers with smoking, justified by the fact that nicotine induces oxidative stress, which produces free radicals, and those attack the lipid layer of cell membranes. Cigarette smoke also induces changes in the properties of muscle fibers, especially in highly oxidative fibers, thereby reducing the number of type I fibers and increasing the Type II b fibers (Larson et al., 1998).

From the inflammatory effects of skeletal muscles, as a result from the nicotine contained in cigarette smoke as a risk factor for pregnant women indoors, and the beneficial effects provided by exercise, which has been widely sought by women during the pregnancy and breastfeeding, these stages intends to investigate the protective effects of exercise on skeletal muscle.

Thus, the objective of this study was to analyze the effects of passive smoking, associated with physical exercise by swimming in the soleus and gastrocnemius skeletal muscles during pregnancy and lactation in animal model.

\section{MATERIAL AND METHOD}

The experimental procedure was approved by the Comitê de Ética em Pesquisa da Faculdade de Ciências e Tecnologia da UNESP - Campus de Presidente Prudente, (process number 24/2009), which followed the "Princípios Éticos na Experimentação Animal" adopted by the Sociedade Brasileira de Ciência em Animais de Laboratório (SBCAL).

Animals and experimental design. For this experiment twenty-four 3-month-old female virgin Wistar rats and eight male Wistar rats (Rattus norvegicus, var. Albina, Rodentia, Mammalia) were kept in individual cages at a temperature of $22 \pm 2{ }^{\circ} \mathrm{C}$, with humidity at $50 \pm 10 \%$, with $12 \mathrm{~h} \mathrm{light/dark}$ cycle (07:00 AM - 07:00 PM) and free access to water and standard pellets Primor®.

To standardize the groups, the 24 female virgin rats underwent a vaginal smear to check the phase of the estrous cycle and then allocated by the proximity of the stages into four groups of six animals each: GF (exposed to cigarette smoke), GC (control), GFN (submitted to the swimming program and exposed to cigarette smoke) and GN (submitted to the swimming program).

Protocol of exposure to cigarette smoke. On the first day of pregnancy the protocol of exposure to cigarette smoke was initiated, which was divided into two phases: first, the adaptation phase, comprising the first five days, where the animals in the groups GF and GFN were exposed to cigarette smoke in the smoke chamber at a temperature of $23 \pm 1{ }^{\circ} \mathrm{C}$ (Czekaj et al., 2002) for $10 \mathrm{~min}$ a day, $250 \mathrm{ppm}$ (parts per million) of $\mathrm{CO}$ (carbon monoxide) measured by BiosystemsTxiPro®specific gas detector The second phase or experimental phase started to last 30 minutes twice a day (morning and afternoon), six days a week with 350 ppm CO of exposure (Edirisinghe et al., 2008).

The animals in GC and GN were submitted to inhalation of compressed air with the same characteristics of time and frequency as the animals exposed to smoke. For the fulfillment of this protocol two hermetically sealed chambers were used, one for groups GF and GFN with inhalation of cigarette smoke and the second for the animals of groups GC and GN with inhalation of only compressed air (Cendon et al., 1997).

Commercially purchased cigarettes were used, comprised of: a mixture of smoke, sugar, cigarette paper, plant extracts and flavoring agents, that produced in each burning: $10 \mathrm{mg}$ tar, $0.9 \mathrm{mg}$ nicotine and $10 \mathrm{mg}$ carbon monoxide, as stated on the product package.

Protocol of the swimming program. The swimming program started on the first day of pregnancy, as reported by Volpato et al. (2006). The swimming sessions were daily, without interruption, in the morning, six days a week for six weeks. In the case of GFN, it was after exposure to cigarette smoke.

The animals in groups GF and GC were submitted to the same conditions of the swimming program, however with water $10 \mathrm{~cm}$ deep per $15 \mathrm{~min}$, to endure the same stress, but it avoiding physical training through swimming. 
Both the protocol of exposure to cigarette smoke, and the swimming program ended on the 21 st day of lactation.

Material collect. The twenty-four female rats were weighed before copulation and on the day of the euthanasia, which was by guillotine on the 21 st day of lactation. After their sacrifice, the surgery for the removal of the gastrocnemius and soleus muscles of the left pelvic limb started, which were weighed. A sample of the gastrocnemius muscle was obtained by a cross section near its origin, specifically in the medial head of the respective muscle.

Histological analysis. The fragments of the muscles were frozen and the fragments frozen slides were obtained with cross sections of $6 \mathrm{~mm}$ at $-20^{\circ} \mathrm{C}$, which were then stained with Hematoxylin Eosin (HE) method for qualitative evaluation of the following characteristics of the soleus and gastrocnemius muscles: shape, size, position of nuclei, phagocytosis, increased endomysial and perimysial and splitting, using Jenapol Zeiss optical microscope (Carl Zeiss®) (Minamoto et al., 1999). Quantitative analysis of morphological characteristics described above was made from the frequency analysis, where the presence or absence of these characteristics was detected in the slides of each animal (Bonfim et al., 2009).

Histochemistry analysis. To demonstrate the activity of oxidative-glycolytic muscle fiber types, other slides were prepared with the method of Nicotinamide Adenine Dinucleotide Tetrazolium Reductase (NADH-TR), which evaluated the level of formazan in the sarcoplasm of muscle fibers of the slides, using the modified Pierce technique by Dubowitz \& Brooke (Dubowitz et al., 2007). By the same method the typing of muscle fibers was carried out, with fibers Type I and II in gastrocnemius muscle (Staron et al., 1999), and later the frequency of types of fiber was verified.

Muscle fiber cross-section area. The possible variations in the size of muscle fibers of the soleus and gastrocnemius muscles were measured through a system of computerized image analysis (NIS-Elements D3.0 - SP7 - Nikon ${ }^{\circledR}$ ) of the slides prepared by the method of NADH-TR. In each image with 100x increase muscle fiber cross-section area $(\mu \mathrm{m})$ in the central region of the section was measured, adapted according to Dubowitz \& Brooke (Dubowitz et al.).

Statistical analysis. For data analysis the SPSS 17.0 software was used, the test Komolgorov-Smirnov was applied, as it was normal, a statistical presentation of mean values followed by their standard deviations was used, and confidence interval (95\%). One-Way ANOVA was used to identify possible differences among groups, when differences were observed, Tukey test was applied. The T-test was applied to compare the values of initial and final weight of rats. For all tests, the level of significance was set at $5 \%$.

\section{RESULTS}

Body Weight. The comparison to the weight of virgin female rats before copulation showed no statistically significant difference among the different groups $(\mathrm{p}=$ 0.734). At the end of the lactation period, the rats were weighed again and there was no significant difference among the experimental and control groups $(\mathrm{p}=0.580)$. Comparing the values of initial and final weight, there was a significant difference for the GC $(\mathrm{p}=0.002), \mathrm{GFN}(\mathrm{p}=$ $0.001)$ and $\mathrm{GN}(\mathrm{p}=0.040)$, and only GF did not show significant difference $(\mathrm{p}=0.108)$.

Muscle weight. The analysis comparing the weight of the gastrocnemius and soleus muscles among the different groups showed no significant difference, for both muscles: soleus $(p=0.9283)$ and gastrocnemius $(p=0.3610)$ among experimental and control groups, as Table I shows.

Muscle Histology. The qualitative analysis of the soleus muscle slides indicated that the GF showed inflammations, increased endomysial and perimysial tissue, necrotic and phagocytized fibers, over $10 \%$ of centralized nuclei, many polymorphic and rounded fibers, and various splittings and coiled. The GC showed normal morphology, fascicular pattern, mostly polygonal fibers with some polymorphic and atrophic fibers. In the group exposed to cigarette smoke and

Table I. Mean values followed by their standard deviations of muscular weight (g), initial and final body weight $(\mathrm{g})$ of rats.

\begin{tabular}{lcccc}
\hline Groups & Inicial weight & Final weight & Soleus muscle & Gastrocnemius muscle \\
\hline GF & $229.5 \pm 14.0$ & $261.1 \pm 38.2$ & $0.127 \pm 0.015$ & $1.479 \pm 0.120$ \\
GC & $236.2 \pm 12.7^{*}$ & $285.7 \pm 30.3$ & $0.129 \pm 0.009$ & $1.392 \pm 0.094$ \\
GFN & $227.2 \pm 18.8^{*}$ & $281.4 \pm 20.5$ & $0.125 \pm 0.012$ & $1.398 \pm 0.130$ \\
GN & $231.3 \pm 8.2^{*}$ & $275.0 \pm 34.0$ & $0.125 \pm 0.007$ & $1.355 \pm 0.120$ \\
\hline
\end{tabular}

$\mathrm{GF}=$ exposed to cigarette smoke; $\mathrm{GC}=\mathrm{control} ; \mathrm{GFN}=$ underwent to the swimming program and exposed to cigarette smoke; $\mathrm{GN}=$ underwent to the swimming program.

*= Significant difference between initial and final weight. $\mathrm{p}<0.05$. 


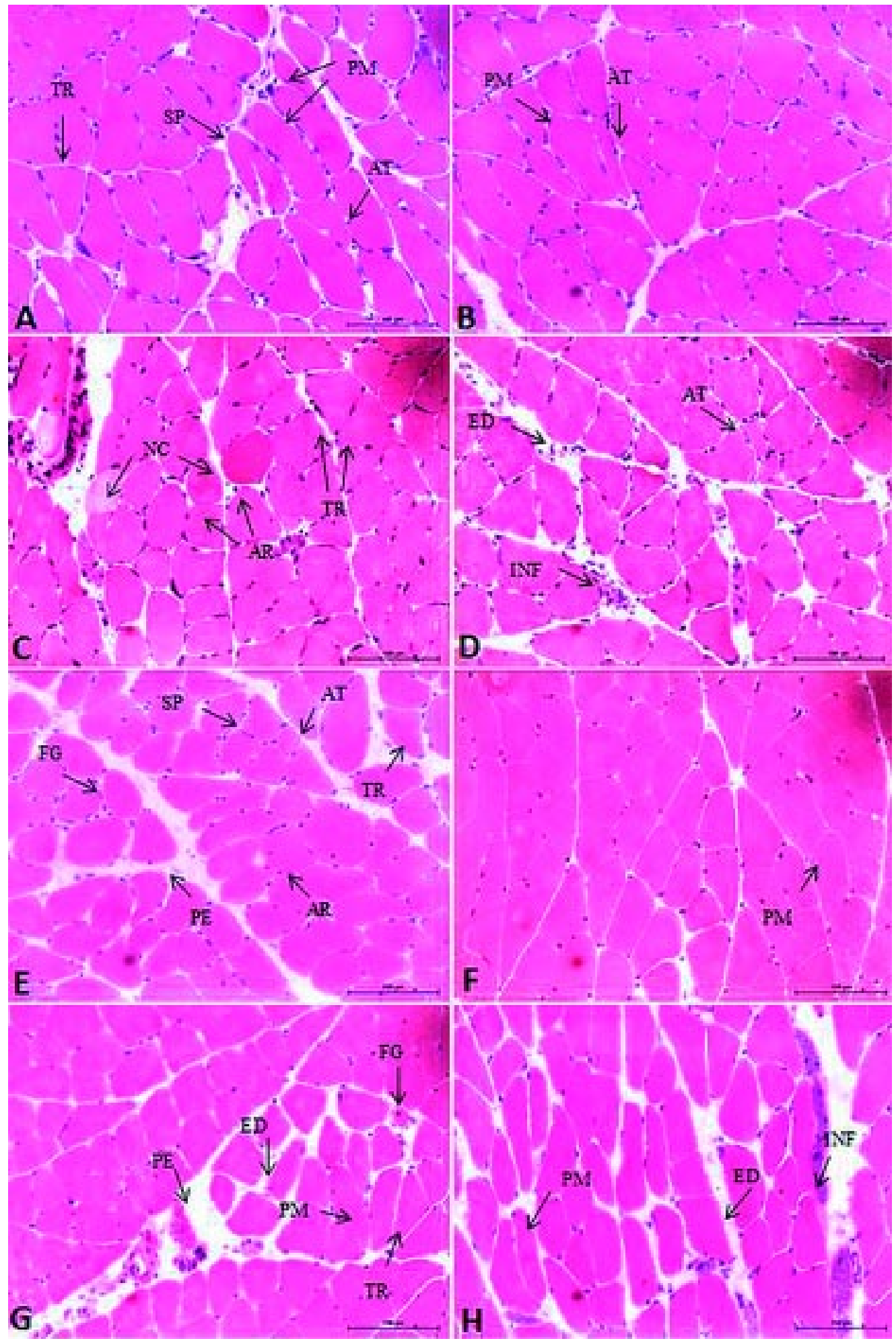

Fig. 1. Soleus muscle fiber cross-section (A-D) and gastrocnemius muscle (E-H) of rats (H-E $500 \mathrm{X})$. A and E) Exposed to cigarette smoke group. B and F) Control group. C e G) Underwent to the swimming program and exposed to cigarette smoke group. $\mathrm{D} \mathrm{e} \mathrm{H}$ ) underwent to the swimming program group. TR= triangularfiber, $\mathrm{AT}=$ atrophic fiber, $\mathrm{AR}=$ rounded fiber, $\mathrm{PM}=$ polymorphic fiber, $\mathrm{FG}=$ phagocytized fiber, $\mathrm{INF}=$ inflammation, $\mathrm{NC}=$ necrosed fiber, $\mathrm{SP}=$ Splitting, $\mathrm{ED}=$ increased endomysium and $\mathrm{PE}=$ increased perimysium. 
submitted to the swimming program (GFN) showed changes in the fibers, for example: rounded fibers, in the process of phagocytosis and splittings, and large extent of inflammations. The rats of group GN showed an increase in endomysium and perimysium, angular and atrophic fibers, few splitting, inflammations and sarcolemal lesion (Fig. 1).

Qualitative analysis of the gastrocnemius muscle revealed changes in the shape of muscle fibers of the group GF as atrophic, hypertrophic, polymorphic, rounded and angular fibers; increase of endomysial and perimysial tissue was also observed, and fibers in the process of phagocytosis and necrosis. In the group GC fibers with polygonal shape, peripheral nuclei and fascicular pattern were found. The histological changes found in the GFN were increase of endomysial and perimysial connective tissue with inflammation, atrophic and polymorphic fibers, and several fibers phagocytized. In the group only exercised (GN), the analysis of the slides indicated that the rats had changes characterized by increase of the endomysial and perimysial tissue with inflammation and injury sarcolemal, and changes in the muscle fibers, like polymorphic, atrophic and angular fibers (Fig. 1).

Table II shows the result of quantitative analysis of histological changes observed in the fibers of soleus and gastrocnemius muscles of rats in each group. The results show that animals of the GFN had the highest frequency of occurrence of histological changes in soleus and gastrocnemius muscles. In animals of the GN group, changes more related to the shape of the fibers were found.
Muscular Histochemistry. The analysis of the soleus muscle slides with reaction of NADH-TR GF indicated loss of enzymatic activity in some fibers, both in the central area and in the periphery of the fiber. In the GC group there was a normal pattern of reaction for most fibers. The GFN group had irregular distribution of reaction for most of the fibers, there were some fibers with loss of reaction, and others had increase of enzyme activity with the presence of formazan aggregates in subsarcolemmal position. The GN group showed in some fibers weak reactive activity in the central and subsarcolemmal area, but also amorphous formazan aggregates in subsarcolemmal position, showing the position of the mitochondria (Fig. 2).

Regarding histochemical analysis of the gastrocnemius muscle, in the GF group no activity was found in various fibers and other fibers with amorphous formazan aggregates in the subsarcolemmal and central area, mostly in oxidative fibers. In the control group (GC) standard reaction for most fibers was observed, with a few of them with increase of enzyme activity in subsarcolemmal position. The GFN group had irregular distribution pattern of the NADH-TR reaction with many fibers showing weak reactive activity in the periphery. In the GN group there was loss of reaction in a few fibers and in other fibers there was presence of formazan in subsarcolemmal position (Fig. 2).

Muscle fiber cross-section area. Variance analysis showed no difference in the values of soleus muscle fiber cross-section area $(\mathrm{p}=0.2472)$, such as in type I fibers of the gastrocnemius muscle $(\mathrm{p}=0.6669)$ and type II fibers $(\mathrm{p}=0.6053)$ among groups, as observed in Table III.

Table II. Analysis of frequency (\%) of morphological characteristics of soleus and gastrocnemius muscle fibers of each group.

\begin{tabular}{lcccccccc}
\hline & \multicolumn{3}{c}{ Soleus muscle } & \multicolumn{4}{c}{ Gastrocnemius muscle } \\
\hline Character istics & GF & GC & GFN & GN & GF & GC & GFN & GN \\
\cline { 2 - 9 } Increased endomysium & 50 & --- & 100 & 80 & 50 & 33 & 83 & 80 \\
Increased perimysium & 67 & 50 & 100 & 100 & 83 & 33 & 83 & 80 \\
Polymorphicfibers & 100 & 83 & 100 & 100 & 100 & 100 & 100 & 100 \\
Angular fibers & 100 & 83 & 100 & 100 & 100 & 100 & 100 & 100 \\
Roundedfibers & 100 & 50 & 100 & 60 & 83 & 33 & 100 & 100 \\
Atrophic fibers & 100 & 17 & 100 & 80 & 100 & 33 & 100 & 60 \\
Hipertrophic fibers & 50 & --- & 67 & 100 & 17 & --- & 50 & 100 \\
Phagocytized fibers & 83 & 17 & 100 & 100 & 100 & 33 & 100 & 60 \\
Necrosed fibers & 50 & --- & 100 & 20 & 33 & --- & 17 & --- \\
Coiled & 17 & --- & --- & --- & --- & --- & --- & --- \\
Centralized nuclei & 33 & --- & 67 & 20 & 33 & --- & 67 & 20 \\
Splittings & 100 & --- & 100 & 40 & 67 & --- & 83 & 20 \\
Inflammation & 100 & 33 & 100 & 80 & 100 & 67 & 100 & 80 \\
Injury sarcolemal & 100 & 33 & 100 & 100 & 100 & 67 & 100 & 80 \\
\hline
\end{tabular}

$\mathrm{GF}=$ exposed to cigarette smoke; $\mathrm{GC}=$ control; $\mathrm{GFN}=$ underwent to the swimming program and exposed to cigarette smoke; $\mathrm{GN}=$ underwent to the swimming program. 
VALSONI, B. C. G.; BONFIM, M. R.; CAMARGO, R. C. T.; ABREU, L. C.; SOUZA, D. R. S. \& CAMARGO FILHO, J. C. S. Effects of passive smoking associated with physical exercise in the skeletal muscles of rats during pregnancy and lactation. Int. J. Morphol., 33(2):497-506, 2015.

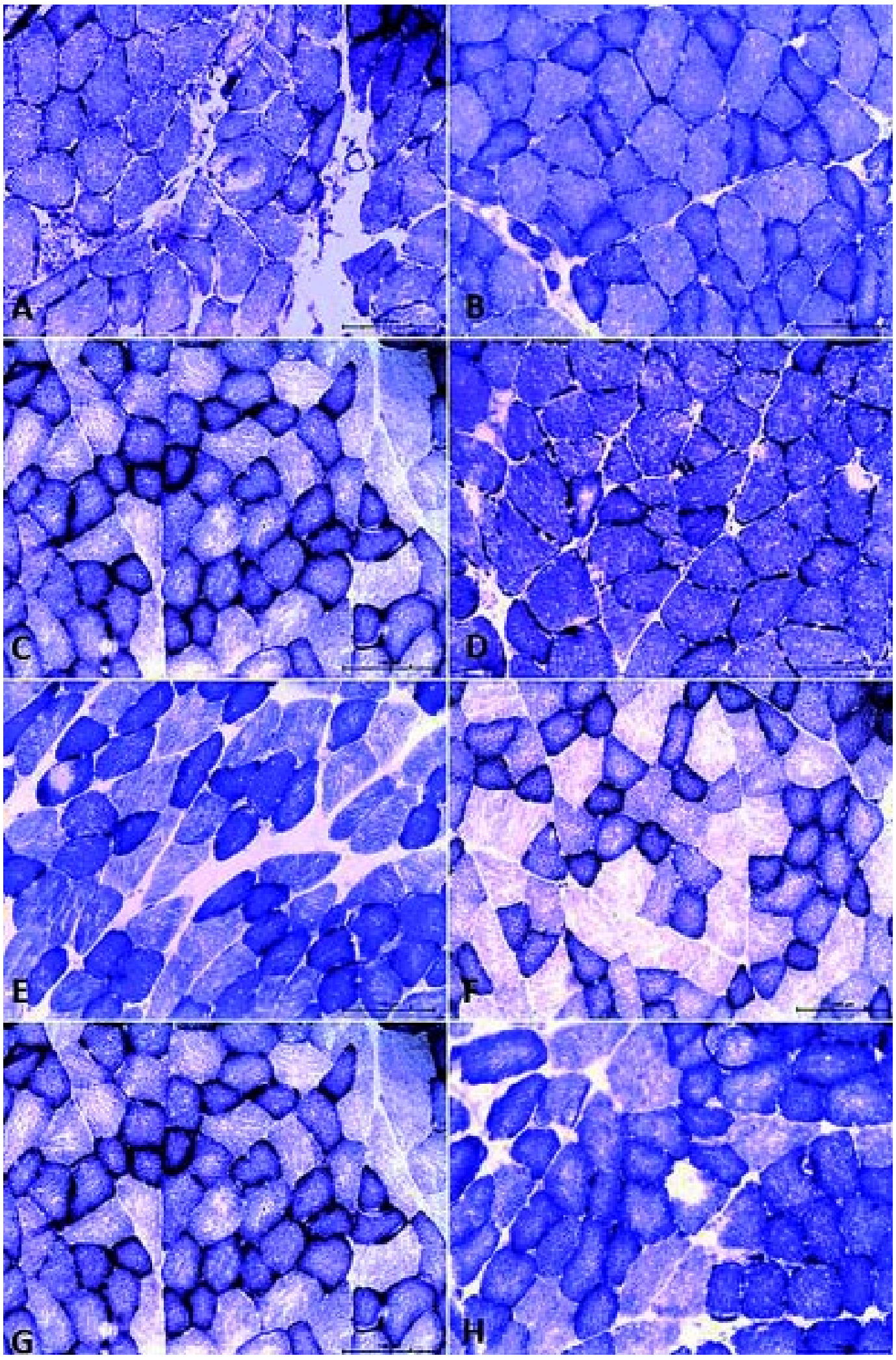

Fig. 2. Soleus muscle fiber cross-section (A-D) and gastrocnemius muscle (E-H) of rats (NADH-TR, 500X). A and E) Exposed to cigarette smoke group. B and F) Control group. C and G) Underwent to the swimming program and exposed to cigarette smoke group. $\mathrm{D}$ and $\mathrm{H}$ ) underwent to the swimming program group. 
Table III. Mean values followed by their standard deviations of soleus and gastrocnemius muscle fibers cross-section area $(\mu \mathrm{m})$ of rats.

\begin{tabular}{lccc}
\hline \multirow{2}{*}{ Groups } & \multirow{2}{*}{ Soleus muscle } & \multicolumn{2}{c}{ Gastrocnmius muscle } \\
\cline { 3 - 4 } & & Type I & Type II \\
\hline GF & $41.80 \pm 3.48$ & $34.37 \pm 2.30$ & $39.89 \pm 3.72$ \\
GC & $44.34 \pm 3.44$ & $33.48 \pm 2.56$ & $40.15 \pm 3.13$ \\
GFN & $40.91 \pm 2.37$ & $32.14 \pm 5.00$ & $38.81 \pm 6.75$ \\
GN & $44.02 \pm 3.84$ & $34.15 \pm 2.58$ & $42.52 \pm 3.41$ \\
\hline
\end{tabular}

$\mathrm{GF}=$ exposed to cigarette smoke; $\mathrm{GC}=$ control; $\mathrm{GFN}=$ underwent to the swimming program and exposed to cigarette smoke; $\mathrm{GN}=$ underwent to the swimming program. $\mathrm{p}<0.05$.

Table IV. Frequency (\%) of fiber types of gastrocnemius muscle of rats.

\begin{tabular}{ccc}
\hline \multirow{2}{*}{ Groups } & \multicolumn{2}{c}{ Gastrocnemius muscle } \\
\cline { 2 - 3 } & Type I (\%) & Type II (\%) \\
\hline GF & 37.37 & 62.63 \\
GC & 37.32 & 62.68 \\
GFN & 29.90 & 70.01 \\
GN & 37.88 & 62.12 \\
\hline
\end{tabular}

$\mathrm{GF}=$ exposed to cigarette smoke; $\mathrm{GC}=$ control; $\mathrm{GFN}=$ underwent to the swimming program and exposed to cigarette smoke; $\mathrm{GN}=$ underwent to the swimming program. $\mathrm{p}<0.05$.

Typing of muscle fibers. After checking the frequency of types of fibers of the gastrocnemius muscle, it was observed that there was no statistically significant difference in the number of type I fibers $(\mathrm{p}=0.5487)$ and type II $(\mathrm{p}=0.4734)$ among the studied groups. The frequencies that were found of types of fiber for the groups are shown in Table IV.

\section{DISCUSSION}

In this study it was found that the body weight of rats increased from the period prior to copulation to the twentyfirst days of lactation, but for the GF group this weight gain was not significant, this lack of weight gain could be explained by the appetite inhibitory effect caused by nicotine contained in side-stream smoke (Perkins et al., 1994). Moreover, there was no difference between groups in initial weight, showing homogeneity before the beginning of protocols.

Our finding, regarding the weight of the rats, corroborates those of Mello et al. (2006). When considering the influence of exposure to cigarette smoke on weight gain of pregnant rats, they concluded that exposure to tobacco reduced their weight gain, but part of this effect was due to the stress of manipulation.

There was no significant difference among groups in the weight in the gastrocnemius and soleus muscles. It infers that muscle overload imposed by pregnancy was insufficient to promote volume increase and muscle hypertrophy, as well as the period of exposure to cigarette smoke was insufficient to reduce the muscle mass of rats. A similar phenomenon was observed by Nakatani et al. (2003) when evaluating Wistar-Kyoto rats for eight weeks with different doses of inhalation of cigarette smoke and they found that there was no difference in muscle weight of the control group, regardless of dosage exposure.

In general, the main data of this study is related to the histology and histochemistry of the soleus and gastrocnemius muscles, whereas in both muscles there were higher incidences of change in the groups exposed to cigarette smoke. Changes such as: inflammatory infiltrates, increase of endomysial and perimysial tissue, necrotic and phagocytized fibers, more than $10 \%$ of centralized nuclei, several polymorphic, atrophic and rounded fibers, and many splittings and curled, reflecting muscle injury in the groups exposed to cigarette smoke.

One of the factors to justify muscle injury in groups exposed to cigarette smoke may be related to the effect of the nicotine contained in cigarette smoke, which promotes vasoconstriction, and releases catecholamines in maternal blood circulation, leading to tesidual hypoxia (Mello et al. 2001; Nakatani et al. 2003). Another relevant fact is related to increase of carboxyhemoglobin (COHb) in blood, which also decreases tecidual oxygenation (Nakatani et al. 2003). Thus, muscle fibers of rats in response to possible low oxygen 
supply may suffer some changes such as atrophy and phagocytosis (Dubowitz et al.).

Nicotine also induces the oxidative stress system causing an imbalance in oxidant/antioxidant in cells, which produces reactive oxygen species that attack lipid membranes. The pro-inflammatory cytokines, especially TNF-a (tumor necrosis factor) are responsible for aggression to the cell membrane, thus high concentrations of TNF-a are associated to muscles injuries (Chattopadhyay \& Chattopadhyay).

As for the histochemical data, irregular distribution of the product was observed in groups GF and GFN, with no reaction in many regions of fibers, showing a decrease in tissue oxygenation, and the fact that higher frequency observed in the soleus and oxidative gastrocnemius muscle fibers of GFN group. The results of this study were to confirm previous studies in both animals (Nakatani et al. 2002, 2003), and human beings (Montes de Oca et al.), where they found a decrease in muscle oxidative capacity.

The rats that only performed physical exercise during pregnancy and lactation also showed changes in histology and histochemistry of soleus and gastrocnemius muscles, although they showed less frequency and intensity. These changes are normal adaptations of skeletal muscles against the exercise, such as alterations in metabolic and structural characteristics, as well as inflammatory processes from micro lesions (Camargo Filho et al., 2006); on the other hand the mitochondrial alterations observed in this group were due to increased metabolic demand.

The histological and histochemical results obtained in the group exposed to cigarette smoke and submitted to the swimming program (GFN) showed great similarity to the results obtained in the group only exposed to cigarette smoke (GF), however, the GFN had a higher frequency and intensity, thus showing that physical exercise intensified the changes on the muscle fibers of animals exposed to nicotine effects, by somatization of stress.

It is known that the physiological demand increased due to physical exercise, and it is related to changes in the number and size of muscle fibers, which are adaptations suffered by the muscle to an overload, thus leading to muscle hypertrophy (Hawke, 2005). Thus, it was expected that the rats that performed exercises by swimming with overload imposed by pregnancy had shown muscle hypertrophy.

However, this fact was not observed in soleus and gastrocnemius muscles after six weeks with 60 minutes of daily exercise, because there was no significant difference in the values of muscle fibers cross-section area among groups. Thus, it must be considered that the overload imposed by the weight gain from pregnancy outcome was not enough for the action of overload training needed to provide muscle hypertrophy, on the other hand it allowed an adaptation process to the training system realized by rats.

Face to muscle response induced by exposure to cigarette smoke, Nakatani et al. (2002) observed that to have reduction in cross-section area of the soleus muscle of rats higher dosage of cigarette smoke it is necessary, however, there was no significant difference to the control group in low doses. The same datum was reported in another study using the EDL muscle (extensor digitorum longus) to type II fibers (Nakatani et al., 2003). In this study there was no reduction in soleus and gastrocnemius muscles fibers cross-section area in groups GF and GFN, although these groups have issued a large number of atrophic fibers. Thus, we can infer that the dosage or the time used in this study were insufficient to influence muscle fibers size significantly.

In a study with smokers it could be verified that changes in skeletal muscle by biopsy of vastus lateralis muscle, characterized by atrophy of type I fibers and increased activity glicolitic (Montes de Oca et al.). Moreover, in studies of cross-sectional area of the quadriceps by magnetic resonance imaging there was no difference between smokers and non-smokers (Morse et al., 2008), it showing that there is no consensus still in literature.

The nicotine present in cigarette smoke can induce changes in metabolic properties, especially in oxidative metabolism, reducing the type I fibers and increasing the Ttype II b (Larsson et al.).

In this study there were no significant differences in gastrocnemius muscle type I and II fibers among the studied groups. This finding corroborates Nakatani et al. (2003) that in their analysis of rats EDL muscle, did not find difference on distribution of fiber type, regardless of dosage of cigarette smoke or muscle region. However, another study found lower percentage of type I fibers and more type II fibers in soleus muscle of spontaneously hypertensive rats with high doses of cigarette smoke (Nakatani et al., 2002).

Moreover, the body weight of rats had not been evaluated during the entire period between pregnancy and lactation limited this study, because from these data we can infer the proportion of overload imposed by pregnancy. And as a future perspective, this study raises the possibility of immunohistochemical analysis for enumeration of inflammatory cells. 
In summary, aerobic exercise is not enough to impeder morphological and histochemical changes caused in an animal model of pregnant and lactating associated with smoking, and stress not influence the muscle fibers cross-section area, nor the fibers types, as well as passive smoking.

\section{ACKNOWLEDGMENTS}

We thank the technician of the Laboratory of Histology, FCT / UNESP, Sidney Siqueira Leirião for collaboration in the research development.

VALSONI, B. C. G.; BONFIM, M. R.; CAMARGO, R. C. T.; ABREU, L. C.; SOUZA, D. R. S. \& CAMARGO FILHO, J. C. S. Efectos del tabaquismo pasivo asociado con el ejercicio físico en los músculos esqueléticos de ratas durante la gestación y lactancia. Int. J. Morphol., 33(2):497-506, 2015.

RESUMEN: EL objetivo fue analizar los efectos del tabaquismo pasivo sobre los músculos sóleo y gastrocnemio asociado con el entrenamiento corporal de natación durante la preñez y lactancia de ratas. Veinticuatro ratas se dividieron en grupos: GF (expuestos al humo de cigarrillo), GC (control), GFN (sometido al programa de natación y expuesto al humo del cigarrillo) y GN (sometido al programa de natación). El procedimiento de exposición al humo del cigarrillo comenzó primer día de preñez, durante 30 min dos veces al día por seis semanas. Durante el mismo período, comenzó el programa de natación, con una duración de 60 min todos los días hasta el día 21 de lactancia. Se extrajeron los músculos sóleo y gastrocnemio, y se realizó el análisis histológico, morfométrico histoquímico y de perfiles de fibra. En la histología, los grupos GF y GFN mostraron infiltraciones, fibras necróticas y fagocitadas, núcleos centralizados, divisiones y enrollamientos; en GN se observaron cambios debido a las adaptaciones de ejercicio tales como infiltraciones, lesión del sarcolema, y fibras polimórficas, atróficas y angulares. En el análisis histoquímico de los grupos GF y GFN hubo actividad enzimática y se formaron agregados amorfos en posiciones subsarcolemales; en el grupo GN se encontraron los mismos cambios en menor frecuencia e intensidad. No hubo diferencias en las medidas de las secciones transversales de las fibras musculares entre los grupos, así como en la frecuencia de los tipos de fibras del músculo gastrocnemio. Se concluye que el ejercicio aeróbico no es suficiente para impedir los cambios morfológicos e histoquímicos causados en un modelo animal de ratas preñadas en periodo de lactancia asociados con el tabaquismo, y el estrés no influye en el tipo y tamaño de las fibras musculares.

PALABRAS CLAVE: Tabaquismo pasivo; Ejercicio físico; Preñez; Lactancia; Músculo esquelético.

\section{REFERENCES}

Baldwin, K. M. \& Haddad, F. Skeletal muscle plasticity: cellular and molecular responses to altered physical activity paradigms. Am. J. Phys. Med. Rehabil., 81(11 Suppl.):S40-51, 2002.

Bonfim, M. R.; Camargo Filho, J. C. S.; Vanderlei, L. C. M.; Padulla, S. A. T.; Accioly, M. F.; Souza, D. R. S. \& Azoubel, R. Muscle response to the association of statin and physical exercise in rats. Int. J. Morphol., 27(4):1155-61, 2009.

Brownson, R. C.; Figgs, L. W. \& Caisley, L. E. Epidemiology of environmental tobacco smoke exposure. Oncogene, 21(48):7341-8, 2002.

Camargo Filho, J. C. S.; Vanderlei, L. C. M.; Camargo, R. C. T.; Francischeti, F. A.; Belangero, W. D. \& Dal Pai, V. Efeitos do esteróide anabólico nandrolona sobre o músculo sóleo de ratos submetidos a treinamento físico através de natação: estudo histológico, histoquímico e morfométrico. Rev. Bras. Med. Esporte, 12(5):243-7, 2006.
Cavalcante, S. R.; Cecatti, J. G.; Pereira, R. I.; Baciuk, E. P.; Bernardo, A. L. \& Silveira, C. Water aerobics II: maternal body composition and perinatal outcomes after a program for low risk pregnant women. Reprod. Health, 6:1, 2009.

Cendon, S. P.; Battlehner, C.; Lorenzi Filho, G.; Dohlnikoff, M.; Pereira, P. M.; Conceicão, G. M.; Beppu, O. S. \& Saldiva, P. H. Pulmonary emphysema induced by passive smoking: an experimental study in rats. Braz. J. Med. Biol. Res., 30(10):1241-7, 1997.

Chattopadhyay, K. \& Chattopadhyay, B. D. Effect of nicotine on lipid profile, peroxidation \& antioxidant enzymes in female rats with restricted dietary protein. Indian J. Med. Res., 127(6):571-6, 2008.

Coleman, T. Reducing harm from tobacco smoke exposure during pregnancy. Birth Defects Res. C Embryo. Today, 84(1):73-9, 2008.

Czekaj, P.; Palasz, A.; Lebda-Wyborny, T.; Nowaczyk-Dura, 
G.; Karczewska, W.; Florek, E. \& Kaminski, M. Morphological changes in lungs, placenta, liver and kidneys of pregnant rats exposed to cigarette smoke. Int. Arch. Occup. Environ. Health, 75(Suppl.):S27-35, 2002.

Dubowitz, V.; Sewry, C. A. \& Lane, R. Muscle biopsy: a practical approach. 3rd ed. Philadelphia, Saunders Elsevier, 2007.

Edirisinghe, I.; Yang, S. R.; Yao, H; Rajendrasozhan, S.; Caito, S.; Adenuga, D.; Wong, C.; Rahman, A.; Phipps, R. P.; Jin, Z. G. \& Rahman, I. VEGFR-2 inhibition augments cigarette smoke-induced oxidative stress and inflammatory responses leading to endothelial dysfunction. FASEB J., 22(7):297-310, 2008.

Hawke, T. J. Muscle stem cells and exercise training. Exerc. Sport Sci. Rev., 33(2):63-8, 2005.

Larsson, L.; Orlander, J.; Ansved, T. \& Edström, L. Effects of chronic nicotine exposure on contractile enzymehistochemical and biochemical properties of fast- and slow-twitch skeletal muscles in the rat. Acta Physiol. Scand., 134(4):519-27, 1998.

Mello, P. R.; Pinto, G. R. \& Botelho, C. The influence of smoking on fertility, pregnancy and lactation. J. Pediatr. (Rio J.), 77(4):257-64, 2001.

Mello, P. R. B.; Okay, T. S. \& Botelho, C. Influência da exposição a fumaça lateral do cigarro sobre o ganho de peso e o consumo alimentar de ratas gestantes: análise do peso e do comprimento dos filhotes ao nascimento. Rev. Bras. Ginecol. Obstet., 28(3):143-50, 2006.

Melzer, K.; Schutz, Y.; Boulvain, M. \& Kayser, B. Physical activity and pregnancy: cardiovascular adaptations, recommendations and pregnancy outcomes. Sports Med., 40(6):493-507, 2010.

Minamoto, V. B.; Grazziano, C. R. \& Salvini, T. F. Effect of single and periodic contusion on the rat soleus muscle at different stages of regeneration. Anat. Rec., 254(2):281-7, 1999.

Montes de Oca, M.; Loeb, E.; Torres, S. H.; De Sanctis, J.; Hernández, N. \& Tálamo, C. Peripheral muscle alterations in non-COPD smokers. Chest, 131(1):13-8, 2008.

Morse, C. I.; Pritchard, L. J.; Wüst, R. C.; Jones, D. A. \& Degens, H. Carbon monoxide inhalation reduces skeletal muscle fatigue resistance. Acta Physiol. (Oxf.), 192(3):397-401, 2008.
Nakatani, T.; Nakashima, T.; Kita, T. \& Ishihara, A. Effects of exposure to cigarette smoke at different dose levels on extensor digitorum longus muscle fibres in WistarKyoto and spontaneously hypertensive rats. Clin. Exp. Pharmacol. Physiol., 30(9):671-7, 2003.

Nakatani, T.; Nakashima, T.; Kita, T. \& Ishihara, A. Responses of exposure to cigarette smoke at three dosage levels on soleus muscle fibers in Wistar-Kyoto and spontaneously hypertensive rats. Jpn. J. Pharmacol., 90(2):157-63, 2002.

Perkins, K. A.; Sexton, J. E.; DiMarco, A. \& Fonte, C. Acute effects of tobacco smoking on hunger and eating in male and female smokers. Appetite, 22(2):149-58, 1994.

Rogers, J. M. Tobacco and pregnancy. Reprod. Toxicol., 28(2):152-60, 2009.

Staron, R. S.; Kraemer, W. J.; Hikida, R. S.; Fry, A. C.; Murray, J. D. \& Campos, G. E. Fiber type composition of four hindlimb muscles of adult Fisher 344 rats. Histochem. Cell Biol., 111(2):117-23, 1999.

Volpato, G. T.; Damasceno, D. C.; Campos, K. E.; Rocha, R.; Rudge, M. V. C. \& Calderon, I. M. P. Avaliação do efeito do exercício físico no metabolismo de ratas diabéticas prenhes. Rev. Bras. Med. Esporte, 12(5):229-33, 2006.

\section{Correspondence to:}

José Carlos Silva Camargo Filho

Departamento de Fisioterapia

FCT / UNESP

Rua Roberto Simonsen, 305, 19060-900

Presidente Prudente, SP

BRAZIL

Fax: (18) 3229-5353

Email: camargo@fct.unesp.br

Received: 14-05-2014

Accepted: 04-03-2015 